\title{
Choroidal melanoma presenting with anterior segment involvement and phthisis bulbi
}

\author{
Abijith Holla, ${ }^{1}$ Sarita R J Gonsalves ${ }^{2}$
}

1 Department of Ophthalmology, Sagarmatha Choudhary Eye Hospital, Lahan, Nepal ${ }^{2}$ Department of Ophthalmology, Kastruba Medical College, Manipal, Karnataka, India

\section{Correspondence to} Dr Sarita R J Gonsalves, gonsalvessarita@gmail.com، drsarita83@rediffmail.com
CrossMark

\section{To cite: Holla A,} Gonsalves SRJ. BMJ Case Rep Published online: [please include Day Month Year] doi:10.1136/bcr-2013200793

\section{DESCRIPTION}

A 70-year-old woman presented with a painless fleshy mass in the right eye of 3 months duration with no history of trauma. She gave a history of cataract surgery in the same eye 4 years ago. Examination revealed an irregular, black, fleshy, lobulated mass with vascularisation extending medially up to the inner canthus (figure 1). The superior extent could not be made out.

The systemic examination was unremarkable. B-scan ultrasonography showed a large domeshaped mass with acoustic hollowness, orbital shadowing with phthisis bulbi. CT orbit showed a decrease in the size of the right eye, soft tissue density in the globe measuring $1.2 \times 1 \mathrm{~cm}$ with calcification (figure 2). MRI orbit-T1 hyperintense

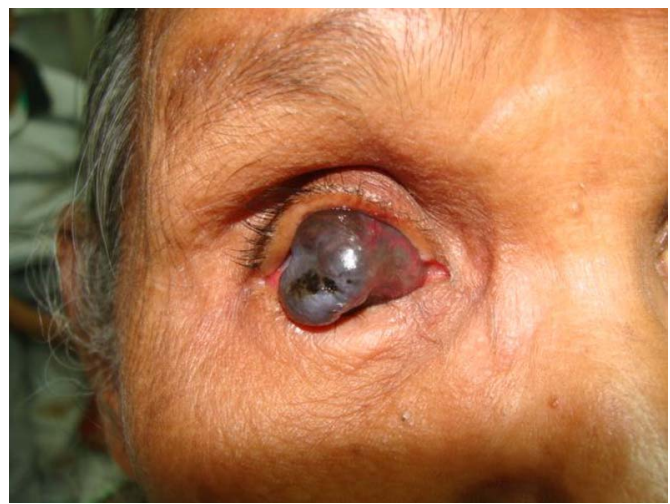

Figure 1 Black, irregular, lobulated, fleshy, vascular mass protruding from the right eye.

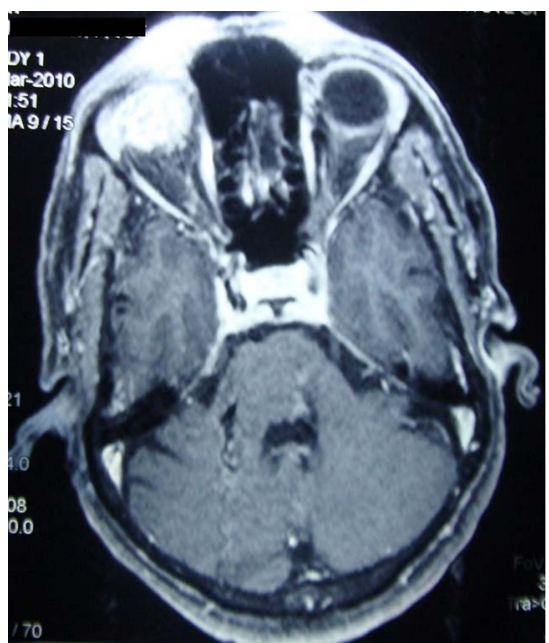

Figure 2 CT orbit showing mass in the posterior segment of the right orbit with calcification measuring $1.2 \times 1 \mathrm{~cm}$ with calcification. and T2 hypointense lesion arising in the posterior segment, extending anteriorly in the right eyeball (figure 3A, B). Enucleation was performed (figure 4), histopathology confirmed spindle cell variety of choroidal melanoma with occasional mitotic activity in the phthisical eye. The optic nerve was free (figure 5). Metastasis workup in the form of chest X-ray, ultrasonography of the abdomen, serum lactate dehydrogenase and liver function tests were normal. The patient was referred to the department of radiation oncology for chemotherapy. Though choroidal melanoma is the commonest primary intraocular malignancy, it has a very low incidence in Asians. In most cases, age at diagnosis is about 55 years, and there is preponderance in $\operatorname{men}^{1}{ }^{2}$, unlike our patient, who was an elderly woman.
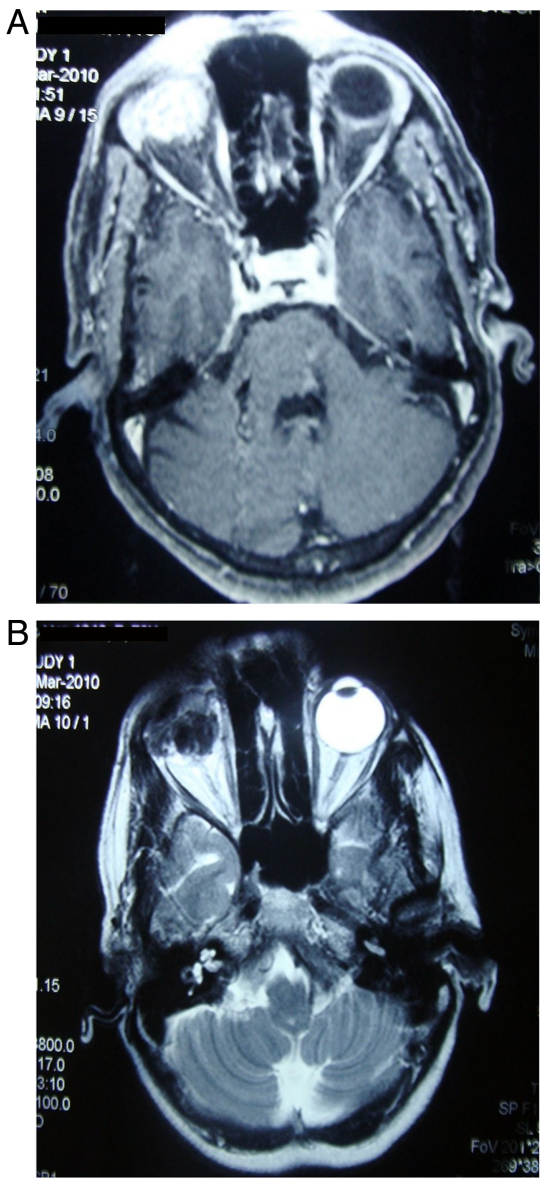

Figure 3 (A) MRI T1-weighted image showing a hyperintense lesion in the posterior segment. (B) MRI T2-weighted image showing hypointense lesion in the posterior segment. 


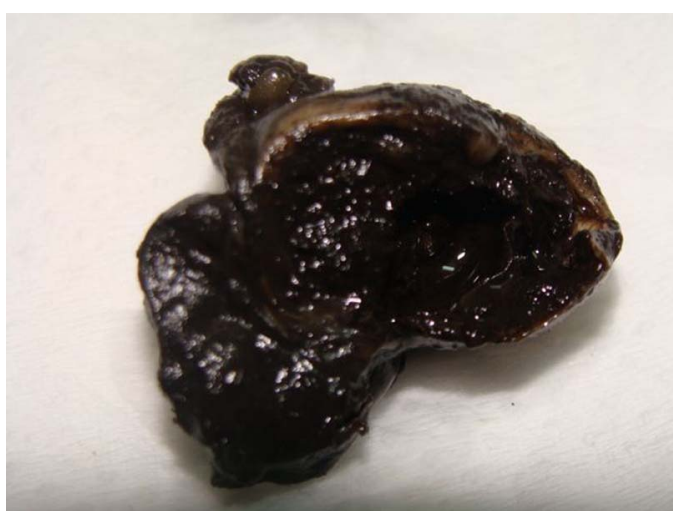

Figure 4 Postenucleation specimen showing necrotic tissue in the right eye.

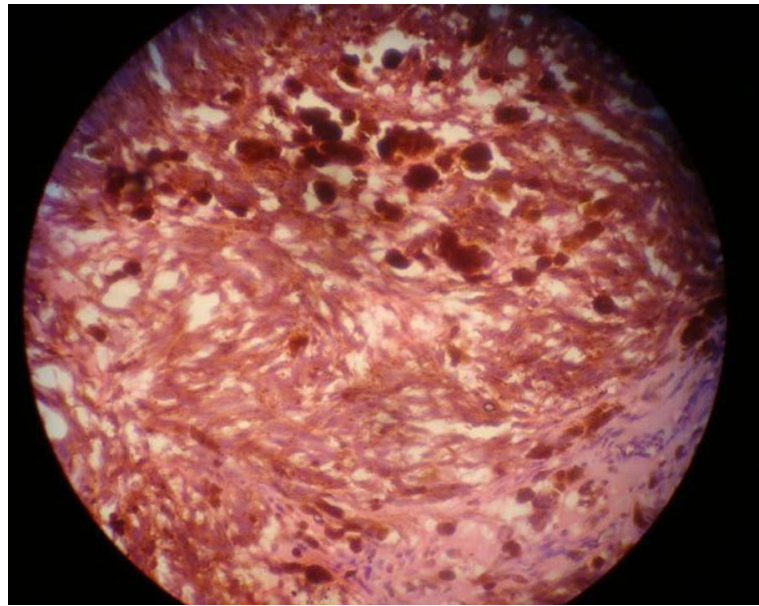

Figure 5 Histopathology of the specimen showing spindle type of melanoma cells.
The spindle cell variety has a better prognosis than the nonspindle cell variety (epithelial, mixed or necrotic). They may be asymptomatic or present with decrease in vision or secondary glaucoma. ${ }^{3}$ Presentation with phthisis bulbi is extremely rare like in our case.

\section{Learning points}

- Malignant melanoma of the choroid which is rare in Asians usually presents with decrease in vision or secondary glaucoma, such a presentation with anterior segment involvement and phthisis bulbi is very rare.

- In our patient the tumour measured more than $1 \mathrm{~cm}^{3}$ and was of the spindle A type with occasional mitoses and no scleral extension. The size of the tumour was the only factor that was suggestive of poor prognosis.

- Enucleation followed by chemoradiation is the preferred treatment modality for choroidal melanoma presenting with anterior segment involvement and phthisis bulbi.

Contributors $\mathrm{AH}$ was involved in the collection and analysis of the data. SRJG was involved in the drafting and the formulation of the data. Both were involved in the final approval.

\section{Competing interests None.}

\section{Patient consent Obtained.}

Provenance and peer review Not commissioned; externally peer reviewed.

\section{REFERENCES}

1 Biswas J, Raghavendra R, Ratra V, et al. Diffuse malignant melanoma of the choroid simulating metastatic tumor in the choroid. Indian J Ophthalmol 2000;48:137-40.

2 Cymbor MJ, Check JM. Choroidal melanoma: a review and case report. J Am Optom Assoc 1998;69:656-65.

3 Sanjay KD, Shatrughan PS, Khem RK. Choroidal melanoma with secondary glaucoma. Southeast Asian J Trop Med Public Health 2003;34:424-6.

Copyright 2013 BMJ Publishing Group. All rights reserved. For permission to reuse any of this content visit http://group.bmi.com/group/rights-licensing/permissions.

BMJ Case Report Fellows may re-use this article for personal use and teaching without any further permission.

Become a Fellow of BMJ Case Reports today and you can:

- Submit as many cases as you like

- Enjoy fast sympathetic peer review and rapid publication of accepted articles

- Access all the published articles

- Re-use any of the published material for personal use and teaching without further permission

For information on Institutional Fellowships contact consortiasales@bmjgroup.com

Visit casereports.bmj.com for more articles like this and to become a Fellow 